Note

\title{
Detection of Listeria monocytogenes from Food Samples by PCR after IMS-Plating
}

\author{
SHIGEKO UEDA ${ }^{1 *}$, TSUTOMU MARUYAMA ${ }^{2}$, \\ AND YOSHIHIRO KUWABARA ${ }^{1}$ \\ 1 Laboratory of Hygiene, Kagawa Nutrition University 3-9-21, Chiyoda, \\ Sakado-shi, Saitama 350-0214, Japan \\ 2 Japan Food Hygiene Association 2-6-1 Jingumae, Shibuya-ku, \\ Tokyo 150-0001, Japan
}

Received 9 May 2006/Accepted 8 July 2006

For rapid, accurate and sensitive detection of Listeria monocytogenes in food samples, colonies developed on the selective agar (Oxford agar) after immunomagnetic separation (IMS) were subjected to polymerase chain reaction (PCR) assay with the prf A1-2 primer pair. The proposed assay system was shown experimentally to be capable of specifically detecting the bacteria from food samples contaminated at more than $10^{2} \mathrm{cfu} / \mathrm{g}$. However, the enrichment culture after a short period of $16 \mathrm{~h}$ with the appropriate selective broth was needed before IMS-plating, because the bacterial contents in most actual food were as low as less than $10^{2} \mathrm{cfu} / \mathrm{g}$. However, even if the enrichment cultivation was employed before IMS, L. monocytogenes was detected within 3 days.

Key words : Listeria monocytogenes /IMS / PCR/ Food

Listeria monocytogenes has been recognized as one of the important foodborne pathogens since the early 1980's when it was demonstrated that outbreaks of foodborne listeriosis were caused by the ingestion of contaminated food such cheese, meat, ice cream and fish (Schlech, et al., 1983; Linnan, et al., 1988; McLauchlin, 1997). In Japan, listeriosis has occurred only sporadically, and a definite foodborne outbreak has been not reported so far (Okutani, et al., 2004). All 13 serovars of $L$. monocytogenes may cause listeriosis in people, but $95 \%$ of isolates from humans have been found to be $1 / 2 a, 1 / 2 b$, or $4 b$. $L$. monocytogenes is widely distributed in the environment. It is found in vegetation, in soils, animal and human feces, sewage, and water. Approximately 2-6\% of healthy people are estimated to be asymptomatic fecal carriers of the organism (Rocourt, 1996), and wild and domestic animals may also be carriers. $L$. monocytogenes can be detected from a wide variety of food, including processed meats, fresh meat and

${ }^{*}$ Corresponding author. Tel: +81-49-282-3717, Fax : +8149-282-3717. fish, raw vegetables, prepared retail foods and dairy products (Bell and Kyriakides, 2002). Although numbers are often very low in these foods, it is necessary to monitor the levels of $L$. monocytogenes in food because multiplication of the bacterium can potentially occur during refrigerated storage. Conventional methods require several days to detect $L$. monocytogenes from various food materials by enrichment culturing in selective broth, isolating the bacteria on selective agar and then differentiating them. At the same time, enzyme-linked immunosorbant assays and assays based on DNA probes or polymerase chain reaction (PCR) tests are readily available. Fluit et al. (1993) detected $L$. monocytogenes in cheese with an immunomagnetic separation (IMS) -polymerase chain reaction (PCR) assay. In this study, we attempted to rapidly, specifically and sensitively detect L. monocytogenes from naturally or artificially contaminated food samples by combining the IMS-plating technique and PCR assay.

The immunomagnetic beads (IMB) used in this study were Dynabeads ${ }^{\circledR}$ anti-Listeria (Dynal A.S., Oslo, Norway) which was coated with polyclonal 
antibodies against Listeria species and suspended at the level of $10^{8}$ particles/ $\mathrm{ml}$ of phosphate buffered saline (PBS) with $0.1 \%$ bovine serum albumin. IMS was performed according to the manufacturer's instructions. After $20 \mu \mathrm{I}$ of the IMB suspension was added to $10 \mathrm{ml}$ of sample suspension and incubated for 20 min with slight agitation at room temperature, the bead-bacteria complexes were separated using a particle concentrator and washed twice with PBS, $\mathrm{pH} 7.5$, containing $0.005 \%$ (W/V) Tween 20 (PBS$\mathrm{T})$, and finally resuspended in $100 \mu \mathrm{I}$ of PBS-T. For isolation of typical $L$. monocytogenes, a $50 \mu \mathrm{I}$ aliquot of the suspension was streaked onto the selective agar plates, and incubated overnight at $37^{\circ} \mathrm{C}$. One typical colony which developed on the selective plate was suspended in $100 \mu \mathrm{l}$ of $10 \mathrm{mM}$ Tris- $\mathrm{HCl}$ containing $1 \mathrm{mM}$ EDTA, pH7.5 (TE buffer), and the suspension was heated for $5 \mathrm{~min}$ at $95^{\circ} \mathrm{C}$. After centrifugation at $14,000 \times \mathrm{g}$ for $60 \mathrm{~s}$, the straight supernatant was subjected to PCR assay.

Four primer sets for detection of $L$. monocytogenes were synthesized on the basis of the DNA sequences of the L. monocytogenes hly, iap or prf genes, as shown in Table 1. PCR was carried out as reported previously (Ueda, et al., 2005). Briefly, a $10 \mu \mathrm{l}$ aliquot of the bacterial DNA extract was added to 90 $\mu \mathrm{I}$ of a reaction solution consisting of $10 \mu \mathrm{I}$ of a 10 fold reaction buffer, $8 \mu \mathrm{I}$ of $2.5 \mathrm{mM}$ dNTP mixture, $100 \mathrm{p} \mathrm{mol}$ of each primer, $2.5 \mathrm{U}$ of Taq DNA polymerase (Takara) and double-distilled water. Then, the sample was overlaid with $70 \mu \mathrm{I}$ of sterile liquid paraffin. The PCR was run for 35 cycles with denaturation at $94^{\circ} \mathrm{C}$ for $60 \mathrm{~s}$, annealing at $55^{\circ} \mathrm{C}$ for $60 \mathrm{~s}$, and extension at $72^{\circ} \mathrm{C}$ for $60 \mathrm{~s}$. For visual detection, a $10 \mu \mathrm{l}$ aliquot of the PCR product was subjected to electrophoresis in a $2 \%$ (W/V) agarose gel (Sigma) with Tris-acetate EDTA buffer. The gel was stained with ethidium bromide and the DNA bands were visualized with UV light.

For determining the effectiveness of several selective agar plates, the bead-bacteria complexes after IMS from the $L$. monocytogenes $4 \mathrm{~b}$ suspension at
$10^{2} \mathrm{cfu} / \mathrm{ml}$ were plated onto several selective agar plates including Oxford agar (Oxoid, Basingstoke, England), PALCAM agar (Oxoid), BCM agar (Brunschwig Chemie, Amsterdam, Netherlands), UVM agar (Oxoid) and/or FDA formulation agar (Oxoid). Almost the same numbers of $4 \mathrm{~b}$ colonies were recovered on all agar media used. Thus, as the plating agar medium after IMS, Oxford agar, usually utilized for isolation of $L$. monocytogenes (lida et. al, 1998; Bell and Kyriakides, 2002), was used in the following experiments.

The specificity of the IMB to Listeria species was examined with $10^{2}-10^{3} \mathrm{cfu} / \mathrm{ml}$ of different bacteria suspended in TE-buffer. The Listeria strains used included 11 strains of $L$. monocytogenes serovars $1 / 2 a, 1 / 2 b, 1 / 2 c$ and 1/4b, and L. innocua. Also, other gram negative and positive bacteria were used as references. Although all Listeria spp. including $L$. monocytogenes and L. innocua developed typical colonies on the Oxford agar plates after the IMS, other bacterial species did not (Table 2). Thus, the IMB was shown to capture only Listeria. For the identification of $L$. monocytogenes, the Listeria colonies on the plates were subjected to the PCR assay. Four primer pairs were first selected for the detection of $L$. monocytogenes by means of the PCR assay. In this trial, the assays were performed with the colonies of various bacterial species including L. monocytogenes developed on Brain Heart Infusion agar plates (Difco). The prfA 1-2 pair reacted exclusively with $L$. monocytogenes, but 3 other pairs cross-reacted minutely or definitely with several species (Table 3 ). The prf A pair was confirmed to react only with $L$. monocytogenes and not with other Listeria spp. including L. innocua, L. ivanovii, L. welshimeri, L. grayi and $L$. seeligeri. Even if the pair did not always react with all $L$. monocytogenes strains, the PCR with the pair was thought to be very effective for detection of the bacteria. Thus, the following experiments were performed using Oxford agar plate as the selective medium for IMS-plating and the prfA primer pair for the PCR assay.

TABLE 1. Oligonucleotide primer pairs used for the detection of $L$. monocytogenes.

\begin{tabular}{|c|c|c|c|c|c|}
\hline No. & Primer set & Target & Sequence $\left(5^{\prime}-3^{\prime}\right)$ & $b p$ & Reference \\
\hline 1 & $\begin{array}{l}\text { LM C } \\
\text { LM D }\end{array}$ & hly $A$ & $\begin{array}{l}\text { TTA CGA ATT AAA AAG GAG CG } \\
\text { TTA AAT CAG CAG GGG TCT TT }\end{array}$ & 161 & $\begin{array}{l}\text { Mengaud et al. } \\
\text { (1989) }\end{array}$ \\
\hline 2 & $\begin{array}{l}\text { Mono A } \\
\text { Mono B }\end{array}$ & iap & $\begin{array}{l}\text { CAA ACT GCT AAC ACA GCT ACT } \\
\text { GCA CTT GAA TTG CTG TTA TTG }\end{array}$ & 371 & $\begin{array}{l}\text { Bubert et al. } \\
(1992)\end{array}$ \\
\hline 3 & $\begin{array}{l}\text { hly } 1 \\
\text { hly-2 }\end{array}$ & hly & $\begin{array}{l}\text { CGG AGG TTC CGC AAA AGA TG } \\
\text { CCT CCA GAG TGA TCG ATG TT }\end{array}$ & 234 & $\begin{array}{l}\text { Bubert et al. } \\
(1997)\end{array}$ \\
\hline 4 & $\begin{array}{l}\text { prfA } 1 \\
\text { prfA } 2\end{array}$ & $\operatorname{prf} A$ & $\begin{array}{l}\text { ACC AAT GGG ATC CAC AAG A } \\
\text { CAG CTG AGC TAT GTG CGA T }\end{array}$ & 467 & $\begin{array}{l}\text { Bubert et al. } \\
\text { (1997) }\end{array}$ \\
\hline
\end{tabular}


TABLE 2. Listeria strains and other bacterial species used for confirming the specificity of the immunomagnetic beads for the capture of $L$. monocytogenes.

\begin{tabular}{|c|c|c|c|}
\hline Species & \multicolumn{2}{|c|}{ Serovar/Toxigenicity/Origin } & Capture $^{a}$ by the beads \\
\hline \multicolumn{4}{|l|}{ Listeria spp. } \\
\hline L. monocytogenes & $1 / 2 a$ & 880278 & + \\
\hline L. monocytogenes & $1 / 2 a$ & 880575 & + \\
\hline L. monocytogenes & $1 / 2 b$ & 900638 & + \\
\hline L. monocytogenes & $1 / 2 b$ & 900418 & + \\
\hline L. monocytogenes & $1 / 2 c$ & 880282 & + \\
\hline L. monocytogenes & $1 / 2 c$ & 900616 & + \\
\hline L. monocytogenes & & 900208 & + \\
\hline L. monocytogenes & $4 b$ & 900226 & + \\
\hline L. monocytogenes & & 110571 & + \\
\hline L. monocytogenes & $4 \mathrm{~b}$ & $\mathrm{CH} 190$ & + \\
\hline L. innocua & SC11 & & + \\
\hline \multicolumn{4}{|l|}{ Gram negative bacteria } \\
\hline Escherichia coli & \multicolumn{2}{|c|}{$\begin{array}{l}10 \text { strains containing type } \\
\text { cultures }\end{array}$} & - \\
\hline Klebsiella aerogenes & \multicolumn{2}{|c|}{ isolated from food } & - \\
\hline Citrobacter freundii & \multicolumn{2}{|c|}{ isolated from food } & - \\
\hline Salmonella Enteritidis & \multicolumn{2}{|c|}{ isolated from egg } & - \\
\hline Salmonella Typhimurium & \multicolumn{2}{|c|}{ isolated from human faeces } & - \\
\hline Vibrio parahemolyticus & \multicolumn{2}{|c|}{ isolated from fish } & - \\
\hline Aeromonas hydrophila & \multicolumn{2}{|c|}{ isolated from water } & - \\
\hline \multicolumn{4}{|l|}{ Gram positive bacteria } \\
\hline Staphylococcus aureus & \multicolumn{2}{|c|}{$\begin{array}{l}7 \text { strains containing } \\
\text { enterotoxigenic producers }\end{array}$} & - \\
\hline Bacillus cereus & \multicolumn{2}{|c|}{$\begin{array}{l}3 \text { strains containing } \\
\text { toxigenic strains }\end{array}$} & - \\
\hline Bacillus subtilis & \multicolumn{2}{|c|}{$\mathrm{PCl} 219$} & - \\
\hline Bacillus licheniformis & \multicolumn{2}{|c|}{ ATCC 14580} & - \\
\hline Bacillus pumilus & \multicolumn{2}{|c|}{ isolate from air } & - \\
\hline Clostridium botulinum & \multicolumn{2}{|c|}{ E type toxin producer } & - \\
\hline Clostridium perfringens & \multicolumn{2}{|c|}{ Hobbs type 13} & - \\
\hline
\end{tabular}

a + , Positive result with the immunomagnetic beads.

-, Negative result with immunomagnetic beads.

The sensitivity of the assay system was evaluated on food samples and human materials contaminated artificially with L. monocytogenes. Food samples used were vegetables and vegetable salads, fruits and fruit juices, milk and dairy products, eggs and egg dishes, meat (pork and beef) and dishes prepared from such meat, and chicken purchased from retail shops. Human materials were feces and blood obtained from a healthy person. A $10 \%$ suspension of each sample was prepared with sterile saline solution, except in the case of milk and blood, and these fluid samples were inoculated with $L$. monocytogenes $4 \mathrm{~b}$ at the level of $10^{1}$ or $10^{2} \mathrm{cfu} / \mathrm{ml}$. The proposed method was shown to be capable of isolating and identifying $L$. monocytogenes from all samples, if the bacteria were present at more than $10^{1} \mathrm{cfu} / \mathrm{ml}$ of the suspension (Table 4). That is to say, $L$. monocytogenes could to be detected by the assay system experimentally if this bacteria were present at more than $10^{2} \mathrm{cfu} / \mathrm{g}$. However, it is normal to find low levels of $L$. monocytogenes at less than $10^{2} \mathrm{cfu} / \mathrm{g}$ in many foods including milk, fish, meat, fruits, and vegetables (Blackburn and McClure, 2002). Therefore, it is predicted that $L$. monocytogenes cannot be detected from the samples contaminated at very low levels of less than $10^{2} \mathrm{cfu} / \mathrm{g}$ by the proposed method.

Some retail meat samples from which $L$. monocytogenes was isolated by the conventional microbiological method were used for the detection of the bacteria. The bacterial contents of all meat samples were estimated to be less than $10^{2} \mathrm{cfu} / \mathrm{g}$, because the bacterial colonies did not appear on the selective agar streaked directly with $0.1 \mathrm{ml}$ of the 
TABLE 3. Specificity of some primer sets for Listeria monocytogenes and other bacterial species.

\begin{tabular}{|c|c|c|c|c|}
\hline \multirow{2}{*}{ Species serovar/strain No. } & \multicolumn{4}{|c|}{ Detection ${ }^{\text {a }}$ with primer pair: } \\
\hline & LM C,D & Mono A-B & hly $1-2$ & prfA 1-2 \\
\hline \multicolumn{5}{|l|}{ L. monocytogenes } \\
\hline $1 / 2 a$ strain 880278 & + & + & + & + \\
\hline $1 / 2 a$ strain 880575 & + & + & + & + \\
\hline $1 / 2 b$ strain 900638 & + & + & + & + \\
\hline $1 / 2 b$ strain 900418 & + & + & + & + \\
\hline 1/2c strain 880282 & + & + & + & + \\
\hline $1 / 2 c$ strain 900616 & + & + & + & + \\
\hline $4 b \quad$ strain 900208 & + & + & + & + \\
\hline 4b strain 900226 & + & + & + & + \\
\hline 4b strain 110571 & + & + & + & + \\
\hline 4b strain $\mathrm{CH} 190$ & + & + & + & + \\
\hline L. innocua SC11 & - & - & - & - \\
\hline Escherichia coli (10 strains) & - & $-(2), \pm(7),+(1)$ & $-(8), \pm(1),+(1)$ & - \\
\hline Klebsiella aerogenes & - & \pm & - & - \\
\hline Citrobacter freundii & - & - & - & - \\
\hline Salmonella Enteritidis & - & - & - & - \\
\hline Salmonella Typhimurium & \pm & \pm & - & - \\
\hline Vibrio parahaemolyticus & - & - & - & - \\
\hline Yersinia enterocolitica & \pm & - & - & - \\
\hline Aeromonas hydrophila & - & - & + & - \\
\hline Staphylococcus aureus (7 strains) & $-(6), \pm(1)$ & $-(2),+(5)$ & - & - \\
\hline Bacillus cereus ( 3 strains) & - & $-(2), \pm(1)$ & - & - \\
\hline Bacillus subtilis & \pm & - & - & - \\
\hline Bacillus licheniformis & \pm & \pm & - & - \\
\hline Bacillus pumilus & \pm & \pm & - & - \\
\hline Clostridium botulinum & - & + & - & - \\
\hline Clostridium perfringens & \pm & \pm & \pm & - \\
\hline
\end{tabular}
a+, positive ; -, negative ; \pm :, indefinite.

TABLE 4. Recovery of $L$. monocytogenes inoculated into the suspension of various food samples and human materials by the PCR assay after IMS-plating.

\begin{tabular}{|c|c|c|c|c|c|c|c|}
\hline \multirow{2}{*}{ Test sample. } & \multicolumn{3}{|c|}{ Inoculation level ${ }^{\mathrm{a}}$ at: } & \multirow{2}{*}{ Test sample } & \multicolumn{3}{|c|}{ Inoculation level ${ }^{\mathrm{a}}$ at: } \\
\hline & 0 & $10^{1}$ & $10^{2}$ & & 0 & $10^{1}$ & $10^{2}$ \\
\hline Lettuce & $-b$ & + & + & Spinach saute & - & + & + \\
\hline Parsley & - & + & + & Spinach soup & - & + & + \\
\hline Cabbage & - & + & + & Vegetable salad & - & + & + \\
\hline Sprouts & - & + & + & Pumpkin salad & - & + & + \\
\hline Leek & - & + & + & Okara salad & - & + & + \\
\hline Welsh onion & - & + & + & Potato salad & - & + & + \\
\hline Tufed stone leek & - & + & + & Seafood salad & - & + & + \\
\hline Carrot & - & + & + & Mashed potatoes & - & + & + \\
\hline Tomato & - & + & + & Raw beef & - & + & + \\
\hline Watermelon & - & + & + & Raw pork & - & + & + \\
\hline Melon & - & + & + & Raw chicken & - & + & + \\
\hline Apple juice & - & + & + & Raw swine liver & - & + & + \\
\hline Orange juice & - & + & + & Hamburger & - & + & + \\
\hline Liquid whole egg & - & + & + & Roasted beef & - & + & + \\
\hline Thick omelet & - & + & + & Swab from surface & - & + & + \\
\hline Milk & - & + & + & & & & \\
\hline Yoghurt & - & + & + & Human blood & - & + & + \\
\hline Cheese & - & + & + & Human faeces & - & + & + \\
\hline
\end{tabular}

a L. monocytogenes was inoculated into $10 \%$ suspension of materials other than juice and milk at the levels of $10^{1}$ and $10^{2} \mathrm{cfu} / \mathrm{ml}$.

$b+$, detectable by the proposed method; -, not detectable by the method. 
sample suspension. L. monocytogenes was isolated only by the enrichment culture (Table 5). Although these samples were directly subjected to the PCR assay after IMS-plating, L. monocytogenes was detected from only 2 among 28 samples (Table 5). Therefore, after $1 \mathrm{ml}$ of the $10 \%$ sample suspension was incubated at $30^{\circ} \mathrm{C}$ for $16 \mathrm{~h}$ in $9 \mathrm{ml}$ of UVM broth (Oxoid) for the enrichment of Listeria, the cultures were subjected to IMS-plating. Consequently, L. monocytogenes was captured and identified from the meat samples by PCR with the prfA primer pair after
IMS plating (Table 5). Thus, when the bacteria are present in the food sample at a very low level of less than $10^{2} \mathrm{cfu} / \mathrm{g}$, it is necessary to carry out the enrichment cultivation with an appropriate selective medium before IMS to detect the bacteria more certainly. The L. monocytogenes contamination ratio of most food is estimated to be between 0.5 and $30 \%$, and the bacterial content is reported to be as low as less than $10^{2} \mathrm{cfu} / \mathrm{g}$ (lida et al., 1998; Blachburn and McClure, 2002). Therefore, the enrichment culture before the IMS may be important to the detection of bacteria

TABLE 5. Detection of L. monocytogenes by the conventional method and PCR after IMS from L. monocytogenespositive meat samples.

\begin{tabular}{|c|c|c|c|c|c|c|}
\hline \multirow{3}{*}{$\begin{array}{l}\text { Sample } \\
\text { No. }\end{array}$} & \multirow{3}{*}{ Material } & \multirow{3}{*}{$\begin{array}{l}\text { L.monocytogenes } \\
\text { counts (cfu/g) } \\
\text { on Oxford and/or } \\
\text { BCM agar }{ }^{1)}\end{array}$} & \multicolumn{4}{|c|}{$\begin{array}{l}\text { Detection of } L \text {. monocytogenes from enrichment and } \\
\text { non-enrichment samples by PCR after IMS-plating. }\end{array}$} \\
\hline & & & \multicolumn{2}{|c|}{ Pre-enrichment ${ }^{2)}$} & \multicolumn{2}{|c|}{ Post-enrichment ${ }^{3)}$} \\
\hline & & & Oxford agar & BCM agar & Oxford agar & $\mathrm{BCM}$ agar \\
\hline A-135 & ground beef & $100>$ & ND & ND & + & + \\
\hline A-144 & ground pork & $100>$ & ND & ND & + & + \\
\hline A-145 & ground pork & $100>$ & ND & ND & + & + \\
\hline$A-146$ & ground pork & $100>$ & ND & ND & + & + \\
\hline A-149 & ground pork & $100>$ & ND & ND & + & + \\
\hline$A-150$ & ground pork & $100>$ & ND & ND & + & + \\
\hline B-115 & ground pork & $100>$ & ND & ND & + & + \\
\hline B-116 & ground pork & $100>$ & ND & ND & + & + \\
\hline B-117 & ground pork & $100>$ & ND & ND & + & + \\
\hline B-119 & chicken & $100>$ & ND & ND & + & + \\
\hline B-125 & ground pork & $100>$ & ND & ND & + & + \\
\hline$B-128$ & ground pork & $100>$ & ND & ND & + & + \\
\hline B-132 & chicken & $100>$ & ND & ND & + & + \\
\hline B-133 & chicken & $100>$ & ND & ND & + & + \\
\hline B-200 & ground pork & $100>$ & ND & ND & + & + \\
\hline B-208 & ground pork & $100>$ & ND & ND & + & + \\
\hline B-215 & chicken & $100>$ & ND & ND & + & + \\
\hline B-216 & chicken & $100>$ & + & ND & + & + \\
\hline B-217 & chicken & $100>$ & + & ND & + & + \\
\hline B-219 & chicken & $100>$ & ND & ND & + & + \\
\hline B-222 & chicken & $100>$ & ND & ND & + & + \\
\hline$E-112$ & lean pork & $100>$ & ND & ND & + & + \\
\hline$E-172$ & lean beef & $100>$ & ND & ND & + & + \\
\hline$E-176$ & lean pork & $100>$ & ND & ND & + & + \\
\hline E-183 & lean pork & $100>$ & ND & ND & + & + \\
\hline E-187 & chicken & $100>$ & ND & ND & + & + \\
\hline E-188 & chicken & $100>$ & ND & ND & + & + \\
\hline E-191 & chicken & $100>$ & ND & ND & + & + \\
\hline \multicolumn{3}{|c|}{$\begin{array}{l}\text { Detection of L. monocytogenes by PCR after IMS- } \\
\text { plating (positives/total) }\end{array}$} & $2 / 28$ & $0 / 28$ & $28 / 28$ & $28 / 28$ \\
\hline
\end{tabular}

1) A $0.1 \mathrm{ml}$ aliquot of $10 \%$ material suspension was streaked onto Oxford or BCM agar. After incubation for $24 \mathrm{~h}$ at $37^{\circ} \mathrm{C}$, the colonies on the plate were enumerated.

2) After $1 \mathrm{ml}$ of $10 \%$ material suspension was mixed with $20 \mu \mathrm{l}$ of immunomagnetic beads for $30 \mathrm{~min}$ at room temperature, the beads which captured Listeria were suspended in $100 \mu$ l of PBS. A $50 \mu$ l aliquot on the suspension was streaked onto Oxford or BCM agar.

3) After $9 \mathrm{ml}$ of FDA LM broth inoculated with $10 \%$ material suspension was incubated for $18 \mathrm{~h}$ at $37^{\circ} \mathrm{C}$, the culture was mixed with $20 \mu \mathrm{l}$ of immunomagnetic beads for $30 \mathrm{~min}$ at room temperature. The beads which captured Listeria were suspended in $100 \mu \mathrm{l}$ of PBS. A $50 \mu \mathrm{l}$ aliquot of the suspension was streaked onto Oxford or BCM agar. 
from samples contaminated at very low levels.

Even if the enrichment procedure is introduced prior to IMS, the proposed assay system may detect L. monocytogenes precisely and rapidly as compared with the conventional method and simultaneously identify the serovar of colonies on the selective agar plate within 3 days.

\section{REFERENCES}

Bell, C. and Kyriakides, A. (2002) Listeria monocytogenes. In Foodborne pathogens: Hazard, risk analysis and control (Blackburn, C.W. and McClure, P.J., ed.), pp.337361, CRC Press, New York.

Border, P.M., Howard, J.J., Plastow, G.S. and Siggens, K.W. (1990) Detection of Listeria species and Listeria monocytogenes using polymerase chain reaction. Lett. Appl. Microbiol., 11, 158-162.

Bubert, A., Kohler, S. and Goebel, W. (1992) The homologous regions within the iap gene allow genus-and species-specific identification of Listeria spp. by polymerase chain reaction. Appl. Environ. Microbiol., 58, 2625-2632.

Bubert, A., Riebe, J., Schnitzier, N., Goebel, W. and Schubert, P. (1997) Isolation of catalase-negative Listeria monocytogenes strains from Listeriosis patients and their rapid identification by anti-p60 antibodies and/or PCR. J. Clin. Microbiol., 35, 179-183.

Fluit, A.C., Torensma, R., Visser, M.J., Aarsman, C.J., Poppelier, M.J., et al. (1993) Detection of Listeria monocytogenes in cheese with the magnetic immunopolymerase chain reaction assay. Appl. Environ. Microbiol., 59, 1289-1293.
Harris, L.J. (2002) Listeria monocytogenes. In Foodborne Diseases $2^{\text {nd }}$ ed (Cliver, D.O. and Rieman, H.P., ed.) pp.137-150, Elsevier Sci. Ltd. New York.

lida, T., Kanzaki, M., Nakama, A., Kokubo, Y., Mayuyama, T., Kaneuchi, C. (1998) Detection of Listeria monocytogenes in humans, animals and Foods. J. Vet. Med. Sci., 60, 1341-1343.

Linnan, M.J., Mascola, L., Lou, X.D., Goulet, V., May, S., Salminen, C., et al. (1988) Epidemic listeriosis associated with Mexican-style cheese. N. Engl. J. Med., 319, 824-328.

McLauchlin, J. (1997) The pathogenicity of Listeria monocytogenes: a public health perspective. Rev. Med. Microbiol., 8, 1-14.

Mengaud, J., Vincente, M.F. and Cossart, P. (1989) Transcriptional mapping and nucleotide sequence of the Listeria monocytogenes hlyA region reveal structural features that may be involved in regulation. Infect. Immun., 57, 3695-3701.

Okutani, A., Okada, Y., Yamamoto, S., Igimi, S. (2004) Nationwide survey of human Listeria monocytogenes infection in Japan. Epidemiol. Infect., 132, 769-772.

Rocourt, L. (1996) Risk factors of listeriosis. Food Control, 7, 195-202.

Schleck, W.F.III, Lavigne, P.M., Bortolussi, R.A., Allen, A.C., Haldane, E.V. et al. (1983) Epidemic listeriosis - evidence for transmission by food. N. Engl. J. Med., 308, 203-206.

Ueda, S. and Kuwabara, Y. (2005) Simultaneous detection of some Yersinia enterocolitica serovars from food and human samples by PCR after IMS-plating. Biocontrol Sci., 10, 111-115. 